\title{
Correlation between leptin and pro-inflammatory cytokines in cortical contusion injury model
}

\author{
Kortikal kontüzyon hasarı modelinde leptin ve proenflamatuvar sitokinler \\ arasındaki korelasyon
}

\author{
Alper KARAOĞLAN, ${ }^{1}$ Osman AKDEMİR, ${ }^{2}$ Nilgün ÇINAR, ${ }^{3}$ Mehmet Alpay ÇAL, ${ }^{1}$ \\ Bilal KELTEN, ${ }^{1}$ Hafize UZUN, ${ }^{4}$ Ahmet ÇOLAK ${ }^{1}$
}

\section{BACKGROUND}

The present study aimed to investigate time-dependent changes in leptin concentrations in brain tissue following experimental traumatic brain injury and to examine the relationship with cytokines.

\section{METHODS}

After circular craniectomy, 33 male Wistar-albino rats were positioned on a stereotaxic frame and subjected to cortical contusion injury and then divided into 3 groups based on the depth of deformation as: $0 \mathrm{~mm}$ (sham controls, $\mathrm{n}=3$ ), $1.5 \mathrm{~mm}$ (moderate injury, $\mathrm{n}=15$ ) and $2.7 \mathrm{~mm}$ (severe injury, $\mathrm{n}=15$ ). Animals were sacrificed on the 1st, 3rd and 5th days post-injury.

\section{RESULTS}

One day after moderate injury, interleukin-1 beta (IL-1 $\beta$ ), IL-6, tumor necrosis factor-alpha (TNF- $\alpha$ ), and leptin levels were found to be markedly increased in the brain tissue. On the 3rd and 5th days, the levels returned to the shamcontrol levels. Following severe injury, IL-1 $\beta$, IL- 6 and TNF- $\alpha$ levels increased in correlation after the 1st day and reached the sham-control levels on the same days. However, leptin tissue levels decreased on the 1st and 3rd days and normalized to the sham-control levels on the 5th day.

\section{CONCLUSION}

Our results showed that the release of leptin is decreased in the early stage of severe injury. Thus, leptin replacement may play an important role in therapy in cases with severe traumatic brain injury.

Key Words: Interleukin-1 $\beta$; interleukin-6; leptin; tumor necrosis factor- $\alpha$; traumatic brain injury.

\section{$A M A C ̧$}

$\mathrm{Bu}$ çalışmada, deneysel travmatik beyin hasarı sonrası beyin dokusundaki zaman bağımlı leptin konsantrasyonlarındaki değişiklik ve sitokinlerle olan ilişki değerlendirildi.

\section{GEREC VE YÖNTEM}

Sirküler kranyektomi sonrası 33 adet erkek Wistar-Albino sıçan stereotaksik çembere yerleştirildi ve kortikal kontüzyon hasarı oluşturuldu. Denekler deformasyon derinliğine göre 3 gruba ayrıldı: $0 \mathrm{~mm}$ (Kontrol, $\mathrm{n}=3$ ), 1,5 mm (Orta hasar, $\mathrm{n}=15$ ), 2,7 $\mathrm{mm}$ (Ciddi hasar, $\mathrm{n}=15$ ). Hayvanlar hasar sonrası birinci, üçüncü ve beşinci günlerde öldürüldü.

\section{BULGULAR}

Orta hasar sonrası ilk gün interlökin 1 beta (IL-1 $\beta$ ), interlökin 6 (IL-6), tümör nekroz faktör alfa (TNF- $\alpha)$ ve leptin seviyelerinin beyin dokusunda belirgin olarak yükseldiği saptandı. Üçüncü ve beşinci günlerde bu seviyelerin kontrol seviyelerine gerilediği görüldü. Ciddi hasar sonrası birinci gün IL-1 $\beta$, IL-6, TNF- $\alpha$ seviyeleri korele olarak yükseldi ve sonrasında kontrol seviyelerine döndü. Buna rağmen leptin seviyeleri birinci ve üçüncü gün azaldı, beşinci günde ise kontrol seviyelerine ulaştı.

\section{SONUÇ}

Ciddi beyin hasarı sonrası erken dönemde leptin salınımının azalması, leptin replasmanının bu olguların tedavisinde önemli rol oynayabileceğini düşündürmektedir.

Anahtar Sözcükler: İnterlökin-1 $\beta$, interlökin-6, Leptin, tümör nekroz faktör- $\alpha$, travmatik beyin hasarı.

\footnotetext{
Departments of ${ }^{1}$ Neurosurgery, ${ }^{3}$ Neurology, Maltepe University, Faculty of Medicine, Istanbul; ${ }^{2}$ Department of Neurosurgery, Taksim Training and Research Hospital, Istanbul; ${ }^{4}$ Department of Biochemistry, 
Traumatic brain injury (TBI) starts with interference with the integrity of an organism and causes local and systemic reactions essential for defense, adaptive and reparative processes. TBI is related with continued production and release of the pro-inflammatory cytokines interleukin-1 beta (IL-1 $\beta$ ), IL-6 and tumor necrosis factor- $\alpha$ (TNF- $\alpha$ ), leading to increased extracellular and cerebrospinal fluid (CSF) levels. ${ }^{[1-3]}$ Cytokines are significant mediators of local changes within the central nervous system (CNS) and systemic changes involving immune, metabolic and endocrine responses..$^{[2]}$ They mediate a multitude of different actions, ranging from neuroprotective to neurotoxic effects. ${ }^{[2]}$ While IL-6 reduced excitotoxic cell damage, overexpression of IL-6 in transgenic mice was associated with sustained gliosis and neuronal cell loss. [2] TNF- $\alpha$ has been shown to reduce excitotoxic cell damage in vitro but to also contribute to posttraumatic functional and structural damage and induce vasogenic edema formation. ${ }^{[2]}$

Leptin, the adipocyte-derived 167-amino acid peptide encoded by the ob gene, is secreted into the circulation and communicates the peripheral nutritional status to specific hypothalamic centers. ${ }^{[4-6]}$ This signal conveys to the brain the nutritional condition of peripheral adipose tissue as regards available energy stores and modulates satiety, thus affecting body mass, metabolic rate and body temperature. ${ }^{[6]}$ Circulating leptin seems to play a critical role in the regulation of the hypothalamo-pituitary-adrenal (HPA) axis. ${ }^{[6]}$ Recent studies suggest that leptin may be involved in the acute response to stress and that its interaction with the HPA axis and the inflammatory cytokine system may be of clinical importance. The expression of leptin can be induced by proinflammatory cytokines. ${ }^{[7,8]}$

The present study aimed to investigate time-dependent changes in leptin concentrations in brain tissue following experimental TBI and to examine the relationship with cytokines.

\section{MATERIALS AND METHODS}

\section{Animals}

Thirty-three male Wistar-albino rats weighing approximately $250-300 \mathrm{~g}$ were used in the present study. The animals were anesthetized using a combination of ketamine $(60 \mathrm{mg} / \mathrm{kg})$ and xylazine $(9 \mathrm{mg} / \mathrm{kg})$. The rats were housed in pairs before and after surgery in a temperature-regulated room with a 12-hour (h) light/dark cycle. All animals were provided food and water. All procedures were approved by the Animal Ethics Committee of the Maltepe University Medical Faculty.

\section{Surgical Procedure}

The skull was exposed with a left coronal scalp incision and reflection of the underlying soft tissues. A circular craniectomy, $7 \mathrm{~mm}$ in diameter, was made in the left parietal bone between the bregma and lambda with the medial edge of the craniectomy $1 \mathrm{~mm}$ lateral to midline. The animal was then positioned on a stereotaxic frame and subjected to cortical contusion injury (CCI). Injury was produced with a convex impactor tip $6 \mathrm{~mm}$ in diameter that was oriented perpendicular to the surface of the brain. The impact was set to a velocity of $4 \mathrm{~m} / \mathrm{s}$ with a sustained depression of 150 $\mathrm{ms}$. Severity of injury was determined by adjusting the depth to which the impactor tip deformed the surface of the brain. Animals were assigned to three groups based on depth of deformation: $0 \mathrm{~mm}$ (sham controls, $\mathrm{n}=3$ ), $1.5 \mathrm{~mm}$ (moderate injury, $\mathrm{n}=15$ ) and $2.7 \mathrm{~mm}$ (severe injury, $n=15$ ). Sham controls underwent identical surgical procedures but were not injured. After injury or sham surgery, the scalp was closed and each animal was given $10 \mathrm{ml}$ of saline subcutaneously. Body temperature was monitored with a rectal probe throughout the procedure and maintained at $36.5-37.5^{\circ} \mathrm{C}$ with a water-circulating heating pad.

\section{Tissue Homogenization}

Animals were sacrificed on the 1st, 3rd and 5th days post-injury and whole brain samples were quickly obtained. Tissue samples were stored at $-80^{\circ} \mathrm{C}$. Brain samples were weighed and homogenized at $4^{\circ} \mathrm{C}$ in 1:3 (w:v) of phosphate-buffered saline (PBS: 137 $\mathrm{mM} \mathrm{NaCl}, 2.7 \mathrm{mM} \mathrm{KCl}$ and $10 \mathrm{mM}$ phosphate buffer, $\mathrm{pH}$ 7.4) in a Teflon/glass homogenizer for cytokines and leptin parameters, and homogenates of $20 \%$ were obtained. Tissue homogenates were sonicated twice at 30 -second (s) intervals. Homogenization and sonication were performed at $4^{\circ} \mathrm{C}$. After sonication, homogenates for biochemical studies were centrifuged at 500 $\mathrm{g}$ for 10 minutes (min) and at $12,500 \mathrm{~g}$ for $15 \mathrm{~min}$. Aliquots of the supernatants were used for both studies.

\section{Measurement of Cytokines by ELISA}

Rat IL-6, IL-1 $\beta$ and TNF- $\alpha$ levels were analyzed by a commercially available ELISA kit (R\&D Systems, Abingdon, Oxon, UK). Analyses of all samples, standards and controls were run in duplicate. The principal methodology for this immunoassay was the same for all cytokines.

\section{Measurement of Leptin by ELISA}

Leptin concentration in homogenates was measured with a rat leptin enzyme-linked immunosorbent assay (ELISA) kit (R\&D Systems, Minneapolis, MN, USA).

\section{Statistical Analysis}

Data are expressed as a percentage of the control \pm SEM (structural equation modeling). Statistical comparisons between groups were performed with the Kruskal-Wallis and Mann-Whitney U tests. P value of 0.05 was considered statistically significant. 
Table 1. IL-1 $\beta$, IL-6, TNF- $\alpha$, and leptin mean levels on the 1st, 3rd and 5th days following moderate injury (pg/g wet tissue)

\begin{tabular}{lcccc}
\hline Groups (Moderate injury) & IL-1 $\beta$ & IL-6 & TNF- $\alpha$ & Leptin \\
\hline Sham control $(\mathrm{n}=3)$ & $234.42 \pm 10$ & $806.96 \pm 81$ & $813.32 \pm 9$ & $1503.3 \pm 41.9$ \\
1 day after injury $(\mathrm{n}=5)$ & $338.28 \pm 17.5$ & $1138 \pm 95.6$ & $1238.5 \pm 74.4$ & $2343.4 \pm 269.6$ \\
3 days after injury $(\mathrm{n}=5)$ & $289.27 \pm 4.2$ & $864.79 \pm 40.6$ & $931.19 \pm 33.8$ & $1531.8 \pm 123.5$ \\
5 days after injury $(\mathrm{n}=5)$ & $216.94 \pm 24.7$ & $728.27 \pm 49.7$ & $851.02 \pm 35.8$ & $1567.4 \pm 35.8$ \\
\hline
\end{tabular}

Table 2. IL-1 $\beta$, IL-6, TNF- $\alpha$, and leptin mean levels on the 1st, 3rd and 5th days following severe injury (pg/g wet tissue)

\begin{tabular}{lcccc}
\hline Groups (Severe injury) & IL-1 $\beta$ & IL-6 & TNF- $\alpha$ & Leptin \\
\hline Sham control $(\mathrm{n}=3)$ & $234.42 \pm 10$ & $806.96 \pm 81$ & $813.32 \pm 9$ & $1503.3 \pm 41.9$ \\
1 day after injury $(\mathrm{n}=5)$ & $383.6 \pm 12.2$ & $1330 \pm 36.5$ & $1410.3 \pm 101.38$ & $954.8 \pm 129.6$ \\
3 days after injury $(\mathrm{n}=5)$ & $277.33 \pm 10.6$ & $879.15 \pm 99.6$ & $911.73 \pm 69.57$ & $754.4 \pm 50.03$ \\
5 days after injury $(\mathrm{n}=5)$ & $226.72 \pm 17.7$ & $738.37 \pm 45.9$ & $735.19 \pm 81.8$ & $1339.8 \pm 81.5$ \\
\hline
\end{tabular}

\section{RESULTS}

During the surgical interventions, 2 animals died and were replaced. One day after moderate injury, IL$1 \beta$, IL- 6 , TNF- $\alpha$, and leptin levels were found to be markedly increased in the brain tissue $(p<0.05)$ (Table 1). On the $3 \mathrm{rd}$ and 5 th days following moderate injury, the levels returned to the sham-control levels. IL-1, IL-6, TNF- $\alpha$, and leptin levels were correlated (Fig. 1). Following severe injury, IL-1, IL- 6 and TNF- $\alpha$ levels increased in correlation after the 1st day, and similar to that observed in moderate injury, the levels returned to the sham-control levels on the 3rd and 5th days (Table 2) (Fig. 2). However, there was a statistically significant decrease in leptin levels on the 1st and 3rd days following severe injury, and these levels reached the sham-control levels on the 5th day. Therefore, following severe injury, leptin levels did not correlate with IL-1, IL-6 and TNF- $\alpha$.

\section{DISCUSSION}

Traumatic brain injury (TBI) can be considered a neuroinflammatory condition of the CNS. Trauma to the brain results in rupture of the blood-brain barrier, leading to accumulation of leukocytes from the systemic circulation, which themselves trigger an inflammatory response characterized by the invasion of circulating immune cells and release of pro-inflammatory cytokines. ${ }^{[1-3]}$ Proinflammatory cytokines are a group of proteins including TNF- $\alpha$, IL- 1 and IL- 6 , which are the key inflammatory mediators, and have similar biological effects. ${ }^{[3]}$

Leptin may act as an inflammatory cytokine and shares structural similarities with cytokines. Therefore, it is recognized as a member of class I cytokine receptor family. ${ }^{[9]}$ Proinflammatory cytokines such as TNF- $\alpha$ or IL-1 $\beta$ can be the main regulatory factors of leptin during inflammation. These complex interactions between proinflammatory cytokines and the HPA axis (partial synergism, partial antagonism) result in leptin synthesis and elevation in leptin plasma levels. ${ }^{[10]}$

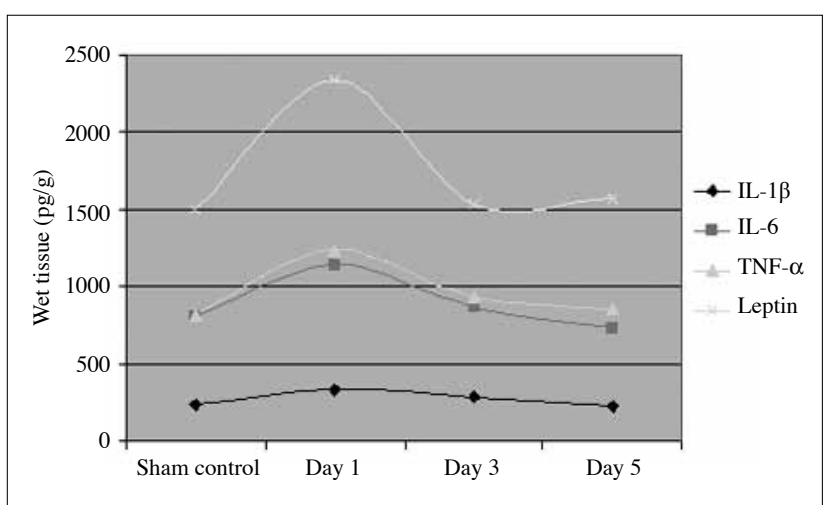

Fig. 1. The correlation between IL- $1 \beta$, IL-6, TNF- $\alpha$, and leptin levels on the 1st, 3rd and 5th days following moderate injury.

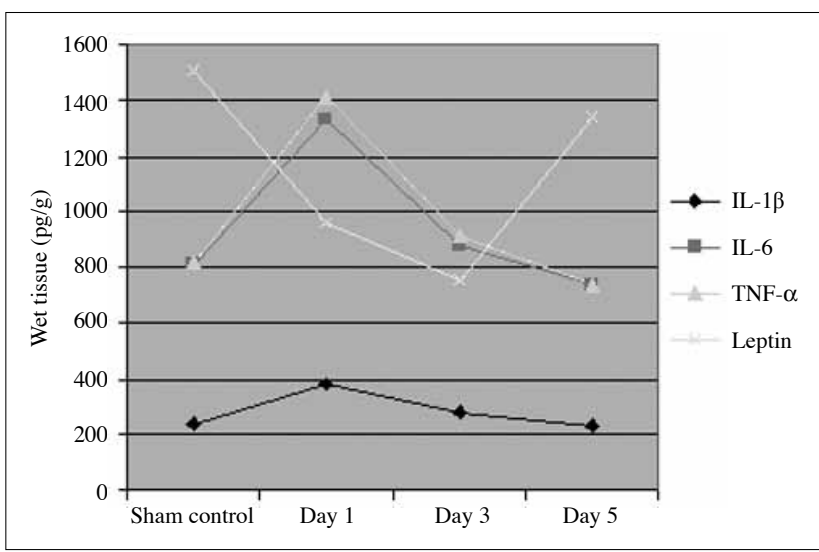

Fig. 2. The correlation between IL-1 $\beta$, IL- 6 , TNF- $\alpha$, and leptin levels on the 1 st, $3 \mathrm{rd}$ and 5 th days following severe injury. 
Leptin, which is primarily synthesized and secreted by adipose tissue, is not only a factor of the inflammatory mediator network, but also functions as an antiobesity factor. Leptin reduces appetite and increases energy consumption by a hypothalamic-dependent pathway. ${ }^{[4]}$ It is well known that leptin also has a number of functions in reproduction, hematopoiesis, regulation of gastrointestinal functions, angiogenesis, regulation of sympathetic nerve system activation, immune homeostasis, determination of bone density, thermogenesis, and brain development. ${ }^{[1]}$ Several recent studies have provided considerable evidence that leptin appears to have a general survival and proliferation-promoting effect, and it is neuroprotective particularly in the more established neurological disease models. $^{[12-14]}$

In our study, in the moderate injury group, elevated levels of leptin, correlated with an increased serum concentration of IL-1 $\beta$, IL 6 and TNF- $\alpha$, were found, whereas in the severe injury group, levels of leptin were correlated negatively with IL- $1 \beta$, IL- 6 and TNF- $\alpha$ on the 1st and 3rd days of the injury (Figs. 1 and 2). Our results showed that the release of leptin is inhibitory in the early stage of inflammation in severe injury. It is interesting that leptin levels decreased while the other inflammatory cytokines (such as TNF- $\alpha$, IL- $1 \beta$ and IL-6) increased in the early stage of inflammation. Low leptin levels have been reported in preterm infants with immaturity of the hypothalamo-pituitary axis and in children with hypothalamic dysfunction. ${ }^{[15-17]}$ Rigaux et al. ${ }^{[16]}$ found a decrease in leptin levels in their study. They thought that both the development of heterotopic bone formation and the decrease in leptin levels may have been related to the presence of severe brain damage involving the hypothalamus. [16] This hypothalamic damage may also impair the anti-osteogenic effects of leptin and thereby contribute to the development of heterotopic bone formation. [16] In our study, we think that our observations are consistent with hypothalamic damage in our animals subjected to the severe injury. Thus, decrease in leptin levels may have been related to the presence of severe brain damage involving the hypothalamus, as Rigaux et al. ${ }^{[16]}$ reported.

Numerous studies have indicated an important role for leptin in the regulation of immune and inflammatory responses. ${ }^{[5,18]}$ Leptin levels increase acutely during infection and inflammation, and may represent a protective component of the host response to inflammation. ${ }^{[5]}$ However, Shi et al. ${ }^{[18]}$ reported that in the early stage of severe traumatism, experimental serum leptin levels decreased, and it is interesting that while leptin level decreased, levels of some inflammatory cytokines (such as TNF- $\alpha$, IL-1 $\beta$ and IL-6) increased in the early stage of inflammation. This may mean that leptin displays an adverse effect on those cytokines or this reversed effect of leptin may be a function of protection and repair. ${ }^{[18]}$

Increased concentrations of inflammatory cytokines have been observed in a variety of disease states, and high plasma leptin levels have been reported in acute conditions of sepsis, septic shock and post-op. ${ }^{[7,10]}$ In contrast to sepsis, plasma leptin levels can be low in chronic infections such as tuberculosis, while leptin shows no change in acquired immunodeficiency syndrome. ${ }^{[19]}$ Some studies on tuberculosis showed a positive correlation between levels of leptin and inflammatory cytokines, ${ }^{[20]}$ while others showed a negative correlation. ${ }^{[21,22]} \mathrm{Kim}$ et al. ${ }^{[21]}$ found that plasma leptin levels were not significantly different between patients with tuberculosis and control subjects. Grunfeld et al. ${ }^{[23]}$ measured leptin levels in patients with acquired immunodeficiency syndrome and found that leptin levels were not increased relative to body fat in patients who were anorectic, were losing weight, or had a history of weight loss. Furthermore, leptin levels did not increase during secondary infections. ${ }^{[23]} \mathrm{We}$ found that plasma leptin levels did not increase during the acute phase of severe injury. The mechanisms regulating the plasma leptin levels and the role of leptin in various conditions have not yet been established. ${ }^{[19]}$

In conclusion, this finding indicates that leptin may participate in the first stage, but not in the progressive stage of the injury. According to our study, leptin levels are correlated with pro-inflammatory cytokines levels in moderate brain injury but not correlated in severe injury. The decrease in leptin levels can be related to the severity of the brain injury. Leptin administration may have multiple short- and long-term advantages over neurologic deficits; therefore, it may be used as a therapeutic agent in acute brain injury as well as chronic neurodegenerative diseases.

\section{REFERENCES}

1. Morganti-Kossmann MC, Satgunaseelan L, Bye N, Kossmann T. Modulation of immune response by head injury. Injury 2007;38:1392-400.

2. Stover JF, Sakowitz OW, Schöning B, Rupprecht S, Kroppenstedt SN, Thomale UW, et al. Norepinephrine infusion increases interleukin- 6 in plasma and cerebrospinal fluid of brain-injured rats. Med Sci Monit 2003;9:BR382-8.

3. Wei HH, Lu XC, Shear DA, Waghray A, Yao C, Tortella FC, et al.NNZ-2566 treatment inhibits neuroinflammation and pro-inflammatory cytokine expression induced by experimental penetrating ballistic-like brain injury in rats. J Neuroinflammation 2009;6:19.

4. Ahima RS, Qi Y, Singhal NS. Adipokines that link obesity and diabetes to the hypothalamus. Prog Brain Res 2006;153:15574.

5. Faggioni R, Feingold KR, Grunfeld C. Leptin regulation of the immune response and the immunodeficiency of malnutrition. FASEB J 2001;15:2565-71.

6. Meisel SR, Ellis M, Pariente C, Pauzner H, Liebowitz M, 
David D, et al. Serum leptin levels increase following acute myocardial infarction. Cardiology 2001;95:206-11.

7. Moses AG, Dowidar N, Holloway B, Waddell I, Fearon KC, Ross JA. Leptin and its relation to weight loss, ob gene expression and the acute-phase response in surgical patients. $\mathrm{Br}$ J Surg 2001;88:588-93.

8. Schulze PC, Kratzsch J, Linke A, Schoene N, Adams V, Gielen $\mathrm{S}$, et al. Elevated serum levels of leptin and soluble leptin receptor in patients with advanced chronic heart failure. Eur J Heart Fail 2003;5:33-40.

9. Matarese G. Leptin and the immune system: how nutritional status influences the immune response. Eur Cytokine Netw 2000;11:7-14.

10. Kain ZN, Zimolo Z, Heninger G. Leptin and the perioperative neuroendocrinological stress response. J Clin Endocrinol Metab 1999;84:2438-42.

11. Lin J, Yan GT, Wang LH, Hao XH, Zhang K, Xue H. Leptin fluctuates in intestinal ischemia-reperfusion injury as inflammatory cytokine. Peptides 2004;25:2187-93.

12. Signore AP, Zhang F, Weng Z, Gao Y, Chen J. Leptin neuroprotection in the CNS: mechanisms and therapeutic potentials. J Neurochem 2008;106:1977-90.

13. Tang BL. Leptin as a neuroprotective agent. Biochem Biophys Res Commun 2008;368:181-5.

14. Zhang F, Chen J. Leptin protects hippocampal CA1 neurons against ischemic injury. J Neurochem 2008;107:578-87.

15. Patel L, Cooper CD, Quinton ND, Butler GE, Gill MS, Jefferson IG, et al. Serum leptin and leptin binding activity in children and adolescents with hypothalamic dysfunction. J Pediatr Endocrinol Metab 2002;15:963-71.
16. Rigaux P, Benabid N, Darriet D, Delecourt C, Chieux V, Dudermel AF, et al. Study of serum factors potentially involved in the pathogenesis of heterotopic bone formation after severe brain injury. Joint Bone Spine 2005;72:146-9.

17. Spear ML, Hassink SG, Leef K, O’Connor DM, Kirwin $\mathrm{SM}$, Locke R, et al. Immaturity or starvation? Longitudinal study of leptin levels in premature infants. Biol Neonate 2001;80:35-40.

18. Shi Y, Yan GT, Lin J. Intestinal ischemia-reperfusion injury made leptin decreased. Regul Pept 2006;15:27-31.

19. Kino Y, Kato M, Ikehara Y, Asanuma Y, Akashi K, Kawai S. Plasma leptin levels in patients with burn injury: a preliminary report. Burns 2003;29:449-53.

20. Cakir B, Yönem A, Güler S, Odabaşi E, Demirbaş B, Gürsoy $\mathrm{G}$, Aral Y. Relation of leptin and tumor necrosis factor alpha to body weight changes in patients with pulmonary tuberculosis. Horm Res 1999;52:279-83.

21. Kim JH, Lee CT, Yoon HI, Song J, Shin WG, Lee JH. Relation of ghrelin, leptin and inflammatory markers to nutritional status in active pulmonary tuberculosis. Clin Nutr [Epub ahead of print], 2010.

22. van Crevel R, Karyadi E, Netea MG, Verhoef H, Nelwan RH, West CE, et al. Decreased plasma leptin concentrations in tuberculosis patients are associated with wasting and inflammation. J Clin Endocrinol Metab 2002;87:758-63.

23. Grunfeld C, Pang M, Shigenaga JK, Jensen P, Lallone R, Friedman J, et al. Serum leptin levels in the acquired immunodeficiency syndrome. J Clin Endocrinol Metab 1996;8:43426. 